\title{
ANALISIS PENYUSUNAN SURAT GUGATAN
}

\author{
Oleh : ENJANG NURSOLIH *)
}

(enjangnorsolih949@gmail.com)

\begin{abstract}
A claim is a letter made by a person who feels aggrieved and submitted to a competent court with the identity of boty the Plainitiff and the Defendant is clear and complete and there is a legal relationship with the problem or event which is the reasons of the claim or petitum which must be formulated with in other words the lawsuit must be clear, compelte and perfect.
\end{abstract}

Keywords: Claim, the Plainitiff and the Defendant

\begin{abstract}
Abstrak
Surat gugatan merupakan surat yang dibuat oleh orang yang merasa dirugikan dan diajukan kepada pengadilan yang berwenang dengan identitas baik pihak Penggugat maupun pihak Tergugat jelas dan lengkap serta ada hubungan hukum dengan permasalahan atau peristiwa yang merupakan alasan-alasan dari pada tuntutan atau petitum yang harus dirumuskan dengan kata lain gugatan harus jelas, lengkap dan sempurna.
\end{abstract}

Kata Kunci: Surat Gugatan, Penggugat, Tergugat

\section{PENDAHULUAN}

Sebelum menyusun Surat Gugatan terlebih dahulu harus mempunyai pengetahuan hukum yang memadai tentang permasalahan yang dihadapi dan langkah berikutnya pengumpulan alat-alat bukti serta perlu juga melakukan identifikasi terhadap orang/ lembaga/objek kemudian dianalisa hukumnya. Artinya dengan permasalahan yang dihadapi sedapat mungkin menggunakan literatur yang lengkap agar lebih akurat.

Setiap orang yang merasa dirugikan dapat mengajukan gugatan terhadap pihak yang dianggap merugikan melalui pengadilan oleh yang berkepentingan. Jadi inisiatif berperkara datang dari pihak yang merasa dirugikan dalam perkara perdata mengenai perselisihan antara kepentingan perseorangan dengan perorangan atau sekelompok orang atau kepentingan suatu badan hukum, pemerintah dengan kepentingan perseorangan dan pihak yang mengajukan tuntutan disebut dengan

\footnotetext{
*) Dosen Tetap Fakultas Ekonomi Universitas Galuh
} 
Penggugat atau kalau lebih dari satu disebut Para Penggugat sedangkan pihak yang digugat disebut Tergugat atau kalau lebih dari satu disebut Para Tergugat.

Di zaman sekarang ini hampir semua gugatan yang masuk ke pengadilan telah berbentuk tertulis baik disusun oleh Penggugat sendiri dan/atau oleh kuasanya.

\section{PEMBAHASAN}

Bahwa dalam menyusun Surat Gugatan terlebih dahulu harus diperhatikan formalitas-formalitas dalam menyusun Surat Gugatan. Sebenarnya format gugatan tidak memiliki bentuk atau format baku. Artinya, seluruh sistematika format gugatan diserahkan kepada pihak Penggugat. Namun, tetap ada beberapa hal yang harus diperhatikan juga harus memenuhi syarat-syarat formal, yaitu :

a. Gugatan harus jelas, baik mengenai subjek, objek maupun posita dan petitumnya. Misalnya, alas hak penggugat atau alas hukum yang menjadi dasar gugatan, identitas penggugat dan tergugat, serta objeknya (surat gugatan yang tidak jelas harus dinyatakan tidak dapat diterima, vide Yurisprudensi Mahkamah Agung Rl, tanggal 05 Juni 1975, Nomor 616 K/Sip/1973 dan yang telah sebagaimana disebutkan di atas);

b. Gugatan harus lengkap, baik mengenai subjek, objek, posita dan petitumnya. Maksudnya harus memuat secara lengkap fakta hukum yang menjadi dasar gugatan, serta konsekuensi logis dari fakta itu terhadap permintaan-permintaan penggugat yang dimuat dalam petitum misalnya, kurang pihak, kurang lengkap identitas subjek maupun objeknya (surat gugatan yang tidak lengkap harus dinyatakan tidak dapat diterima, vide Yurisprudensi Mahkamah Agung RI, tanggal 28 Nopember 1956, Nomor 195 K/Sip/1955).

c. Gugatan harus sempurna, artinya selain memperhatikan syarat jelas dan lengkap, juga harus memperhatikan logika-logika hukum yang dapat menimbulkan konsekuensi, bahwa hal-hal tersebut harus diajukan dalam surat gugatan. Misalnya, untuk perkara perbuatan melawan hukum, harus ada petitum yang menyatakan bahwa tergugat telah melakukan perbuatan melawan hukum. untuk perkara ingkar janji, harus ada petitum yang menyatakan bahwa perjanjian yang dibuat antara penggugat dengan tergugat adalah sah, serta petitum yang menyatakan bahwa tergugat telah ingkar janji. Untuk perkara waris harus ada petitum yang menyatakan bahwa barang sengketa adalah barang peninggalan pewaris yang belum dibagi (boedel). 
Surat Gugatan yang diajukan pada pengadilan setidaknya memuat hal-hal sebagai berikut :

1. Kop surat

2. Nomor surat (jika ada)

3. Lampiran (jika ada)

4. Titel/hal gugatan

Merupakan kata-kata/kalimat pendek yang biasa digunakan dalam surat gugatan, yang dicantumkan di bawah tulisan tempat surat gugatan pada bagian sebelah kiri dari lembar awal dan dalam menentukan judul harus diperhatikan dengan isi karena harus sesuai/sinkron agar gugatan tidak menjadi kabur/obscuur libel.

5. Tanggal gugatan dan menyebutkan kota dimana gugatan tersebut di buat. Untuk tanggal gugatan dapat ditempatkan di awal atau di akhir gugatan.

Untuk menunjukan tempat dan waktu dibuatnya surat gugatan karena konsekwensi hukumnya, bisa saja surat guatan prematur dan /atau kadaluarsa pencantumannya dapat diletakan dibagian atas atau pada bagian bawah dari lembar terakhir surat gugatan seperti pada umumnya surat-surat resmi lainnya.

6. Alamat tujuan gugatan (misalnya Kepada Yang Terhormat Ketua Pengadilan)

Bahwa surat gugatan harus diajukan kepada ketua pengadilan tertentu untuk menentukan pengadilan yang berwenang mengadili dan berpedoman terhadap ketentuan kompetensi/kewenangan absolut serta kewenangan relatif.

Menurut Pasal 118 ayat (1) HIR / RIB

Gugatan harus diajukan kepada ketua pengadilan wilayah hukum tempat kediaman/tempat tinggal Tergugat.

Jika tergugatnya lebih dari satu orang, maka Penggugat dapat memilih salah satu dari Tergugat (Pasal 118 ayat (2) HIR/RBG).

Apabila alamat Tergugat tidak diketahui, maka diajukan ditempat tinggal terakhir di ketahui dan apabila tempat tinggal terakhir tidak diketahui diajukan di Wilayah Hukum alamat Penggugat dan berbeda apabila objek gugatan adalah barang tidak bergerak/benda tetap Penggugat dapat memilih apakah diajukan di tempat tinggal Tergugat atau di alamat tempat barang tidak bergerak itu berada (Pasal 118 ayat (3) HIR/RIB). 
Dalam hal ada alamat pilihan yang biasanya dicantumkan dalam suatu perjanjian, maka diajukan di alamat yang ditunjuk dalam surat perjanjian (Pasal 118 ayat (4) HIR/RIB).

Dalam hal ada alamat pilihan yang biasanya dicantumkan dalam suatu perjanjian, maka diajukan di alamat yagn ditunjuk dalam surat perjanjian (Pasal 118 ayat (4) HIR/RIB) yang paling penting harus dipertimbangkan efektifitas, baik mengenai proses, biaya maupun tenaga.

7. Salam Pembuka

8. Pengenalan identitas Penggugat, jika Penggugat tidak menguasakan perkaranya atau identitas Penggugat dan Kuasanya jika Penggugat menguasakan kepada pihak lain (Advokat).

9. Penyebutan identitas Tergugat dan Kuasanya.

Identitas merupakan ciri-ciri dari pihak Penggugat atau Para Penggugat dan Tergugat atau Para Tergugat atau Turut Tergugat yang bermacam-macam kualifikasinya bisa dalam kapasitas/kualitas hukum sebagai orang pribadi yang bertindak untuk diri sendiri, bisa untuk orang lain dan bisa untuk atas nama sebuah lembaga/persekutuan baik badan hukum atau bukan badan hukum. Serta identitas kusanya kalau menggunakan kuasa.

10. Uraian duduk perkaranya (Posita). Dalam posita ini untuk menjamin agar putusan hakim dapat dilaksanakan, maka perlu diminta sita jaminan terhadap obyek sengketa kepada Majelis Hakim.

Merupakan uraian tentang hal-hal/dalil-dalil yang menjadi dasar atau alasan hukum dengan kata lain bagian yang menguraikan kejadian/peristiwa dan bagian yang menguraikan tentang dasar hukumnya, untuk itu dibutuhkan pengetahuan hukum yang memadai khususnya yang ada kaitannya dengan materi gugatan agar dapat melakukan analisa terhadap fakta riil yang ada.

Mengenai seberapa jauh harus dicantumkannya perincian tentang peristiwa yang dijadikan dasar tuntutan ada beberapa pendapat :

a. Menurut Substantieringstheori, tidak cukup disebutkan hukum yang menjadi dasar tuntutan saja, tetapi harus disebutkan pula kejadian-kejadian yang nyata yang mendahului peristiwa hukum yang menjadi dasar gugatan itu, dan menjadi sebab timbulnya peristiwa hukum tersebut misalnya : bagi Penggugat yang menuntut miliknya, selain menyebutkan bahwa sebagai pemilik, ia juga harus menyebutkan asal usul pemilikan tersebut. 
b. Menurut individualiseringstheori sudah cukup dengan disebutkannya kejadiankejadian yang dicantumkan dalam gugatan yang sudah dapat menunjukkan adanya hubungan hukum yang menjadi dasar tuntutan. Dasar atau sejarah terjadinya hubungan tersebut tidak perlu dijelaskan, karena hal tersebut dapat dikemukakan di dalam sidang-sidang yang akan datang dengan disertai pembuktian (R. Soeroso, 2006 : 27).

c. Menurut putusan Mahkamah Agung sudah cukup dengan disebutkannya perumusan kejadian materiil secara singkat (Putusan MA tanggal 15 Maret 1972 No. 145 k/Sip 1971).

Posita harus disusun sedemikian rupa, dengan memperhatikan hal-hal berikut ini :

a. Etika, artinya menggunakan gaya bahasa yang sopan, tidak menyerang kehormatan atau merendahkan pihak lain, khususnya tergugat (lawan).

b. Estetika, artinya menggunakan gaya bahasa yang indah, sehingga enak dibaca dan mudah dipahami, serta tidak monoton.

c. Bahasa baku, artinya tidak menggunakan kalimat yang berbelit-belit dan atau panjang, tetapi cukup sederhana, singkat, jelas dan tegas.

d. Memilih kata-kata yang tidak bermakna ganda, sehingga dapat dihindari perbedaan penafsiran antara penggugat, tergugat dan hakim.

e. Konsisten dalam menggunakan istilah, artinya tidak menggunakan istilah yang berbeda-beda untuk hal tertentu, misalnya, tim 9, panitia IX, ketua, pimpinan, pemimpin, tanah sengketa, objek perkara, tanah terperkara dan lain-lain.

f. Sinkron artinya tidak kontradiktif diantara bagian-bagian posita maupun dengan petitum.

g. Menggunakan kalimat yang bermakna hubungan sebab akibat (kausal) artinya fakta hukum yang ditampilkan dalam kalimat awal, akan membawa akibat hukum yang diuraikan dalam kalimat berikutnya, misalnya : oleh karena tergugat menguasai tanah sengketa tanpa alas hak yang sah, maka perbuatan tersebut merupakan perbuatan melawan hukum.

h. Menyusun posita dengan menggunakan kronologi peristiwa hukum, untuk memudahkan pemahaman yang runtut, guna meyakinkan hakim akan alas hak yang sah bagi penggugat, dengan memberi nomor urut untuk masingmasing alinea, serta memberi nomor halaman untuk setiap lembar kertas yang digunakan (Achmad Fauzan, 2007 : 60). 
11. Uraian apa yang diminta atau dituntut (Petitum)

Petitum gugatan adalah berisi tentang permintaan-permintaan yang diajukan oleh penggugat kepada hakim/pengadilan, berkaitan dengan adanya berbagai pertimbangan hukum, yang telah diuraikan dalam posita. Oleh karena itu, di dalam membuat petitum harus memperhatikan hal-hal, sebagai berikut :

a. Kesesuaian / sinkronisasi dengan posita, artinya alasan-alasan yang telah diuraikan dalam posita itulah yang harus digunakan sebagai dasar untuk mengajukan permintaan. Contoh I, uraian dalam posita sudah berdasarkan hukum, sehingga petitum pertama yang diminta adalah : Mengabulkan gugatan penggugat untuk seluruhnya. Contoh II, uraian yang membuktikan tergugat telah menguasia tanah sengketa tanpa alas hak yang sah, sehingga merupakan perbuatan melawan hukum, untuk itu petitum yang diminta : Menyatakan, bahwa tergugat telah melakukan perbuatan melawan hukum.

b. Tidak kontradiksi, artinya petitum tidak boleh kontradiksi dengan posita maupun dengan bagian petitum lainnya. Contoh : dalam posita diuraikan tentang tergugat telah menguasai tanah sengketa tanpa alas hak yang sah, sehingga merupakan perbuatan melawan hukum, akan tetapi dalam petitum, lupa tidak disebutkan adanya perbuatan melawan hukum tergugat itu, misalnya dengan formulasi kalimat : Menyatakan bahwa tanah sengketa milik sah Penggugat. Menghukum Tergugat untuk menyerahkan tanah sengketa kepada Penggugat. Contoh II : Menyatakan Pemutusan Hubungan Kerja (PHK) yang dilakukan oleh Tergugat kepada Penggugat adalah tidak sah. Menghukum Tergugat untuk membayar ganti rugi. Padahal PHK tidak sah (recht wege nietig) artinya harus dikembalikan kepada keadaan semula, yaitu adanya hubungan kerja, seolah-olah tidak pernah terjadi PHK. Sehingga mestinya, formulasinya adalah : Menyatakan PHK yang dilakukan oleh tergugat kepada penggugat tidak sah. Menghukum tergugat untuk mempekerjakan kembali penggugat, terhitung sejak putusan ini diucapkan. Menghukum tergugat untuk membayar gaji dan hak-hak lain yagn sah kepada penggugat, terhitung sejak tanggal PHK, ditambah ganti rugi sebesar sekian juta rupiah.

c. Orang yang ditetapkan dalam petitum harus sebagai pihak dalam perkara Contoh : Menyatakan, bahwa penggugat, tergugat maupun saudara penggugat dan tergugat yang bernama Amin adalah ahli waris yang sah dari 
suami - istri almarhum dan almarhumah Jalil dan Romlah yang berhak atas harta peninggalannya, yaitu barang sengketa. Padahal Amin tidak menjadi pihak dalam perkara.

d. Petitum harus jelas dan tegas, artinya apa yang diminta harus jelas dan tegas, sehingga tidak membingungkan hakim. Berikut ini contoh-contoh petitum tidak jelas (obscuur libel).

Contoh I : Menetapkan hak penggugat atas tanah sengketa. Padahal, seharusnya disebutkan berapa yang diminta oleh penggugat, misalnya menetapkan hak penggugat atas tanah sengketa adalah sebesar $1 / 2$ (setengah) bagian.

e. Petitum tidak boleh bersifat negatif, artinya berisi tentang perintah untuk tidak berbuat. Contoh : Menghukum tergugat supaya tidak mengambil tindakan yang bersifat merusakkan bangunan sengketa.

f. Petitum harus runtut dan disusun sesuai dengan poin-poin posita, serta diberi nomor urut. Misalnya, dalam perkara ingkar janji, harus dimintakan terlebih dahulu tentang pengesahan perjanjian yang diingkari oleh tergugat.

Contoh : a. Mengabulkan gugatan penggugat untuk seluruhnya.

b. Menyatakan bahwa perjanjian yang dibuat antara penggugat dengan tergugat pada tanggal 1 Januarii 2019 adalah sah.

c. Menyatakan tergugat telah ingkar janji (wanprestatie).

Menghukum tergugat untuk memenuhi isi perjanjian dengan cara menyerahkan barang yang menjadi objek perjanjian, yaitu 1 unit mesin fotokopi merek Canon, dengan seri Canon IR5000, selambat-lambatnya 7 (tujuh) hari, terhitung sejak putusan ini diucapkan.

d. Menghukum tergugat untuk membayar penggantian biaya sewa fotokopi, sebagai akibat keterlambatan dalam penyerahan, sebesar sekian rupiah, ditambah ganti rugi berupa keuntungan yang semestinya didapat dari operasional mesin fotokopi, sebesar sekian rupiah per hari, terhitung sejak tanggal 1 Januari 2019.

e. Dan seterusnya ..... terakhir, menghukum tergugat untuk membayar semua biaya yang timbul dalam perkara ini. 
Permintaan atau tuntutak baik primer/pokok atau tambahan dan subsidiair/ pengganti yang diajukan / diharapkan penggugat agar diputuskan oleh hakim, oleh karena itu harus dirumuskan secara jelas dan tegas, oleh karena itu fetitum harus sinkronisasi dengan posita tidak kontradiksi dan disusun sesuai dengan poin-poin posita sedangkan jenis-jenis petitum dapat dikelompokan sebagai berikut :

a. Petitum declaratoir, yang isinya bersifat menerangkan atau menyatakan keabsahan.

Contoh : menyatakan perjanjian yang dibuat antara penggugat dengan tergugat adalah sah.

b. Petitum consitutif, yang isinya bersifat menciptakan atau meniadakan suatu keadaan hukum. contoh I (menciptakan keadaan hukum) : Menyatakan bahwa penggugat dan tergugat adalah ahli waris sah dari almarhum dan almarhumah suami-istri Kromorejo dengan Markonah. Contoh II (meniadakan keadaan hukum) : Menyatakan, bahwa hubungan ikatan perkawinan antara penggugat dengan tergugat putus karena peceraian.

c. Petitum condemnatoir, yang isinya bersifat hukuman yang dapat dipaksakan dengan cara eksekusi. Dalam praktik, sering terjadi suatu perkara telah dimenangkan oleh pihak penggugat, akan tetapi penggugat tidak dapat menikmati kemenangannya, karena putusannya tidak dapat dieksekusi (non executable). Salah satu sebabnya adalah petitumnya tidak ada yang bersifat condemnatoir (hanya bersifat constitutif atau declaratoir saja). Contoh : Menghukum tergugat untuk menyerahkan tanah sengketa dalam keadaan kosong dan baik, tanpa beban apa pun juga kepada penggugat, selambatlambatnya 7 (tujuh) hari, terhitung sejak putusan diucapkan.

d. Petitum provisionil, yang isinya bersifat permintaan kepada hakim agar diadakan tindakan pendahuluan, selama proses pemeriksaan perkara berlangsung, misalnya agar pihak penggugat tidak makin dirugikan oleh tindakan tergugat. Contoh : memerintahkan kepada tergugat untuk menangguhkan pembangunan rumah di atas tanah sengketa, sampai dengan adanya putusan pengadilan yang berkekuatan hukum tetap (inkracht van gewijsde) atas perkara ini. Apabila perintah ini dilanggar, kepada tergugat harus dihukum untuk membayar ganti rugi kepada penggugat, sebesar sekian 
juta, untuk tiap-tiap kali terjadi pelanggaran dan dapat ditagih secara tunai dan sekaligus, seketika setelah terjadinya pelanggaran.

e. Petitum alternatif, yang isinya bersifat pilihan, dengan tujuan memberi kesempatan kepada hakim untuk menjatuhkan pilihan, sesuai dengan ketentuan hukum yang berlaku. Petitum model ini harus dibuat dengan cara mengajukan permintaan kepada hakim agar menjatuhkan pilihan yang pertama dan apabila hakim tidak berkenan, supaya menjatuhkan pada pilihan yang kedua dan seterusnya. Tetapi, dalam praktik, biasanya hanya ada dua pilihan dan kadang-kadang ada tiga pilihan, dengan model primair, subsidair dan ex aequo et bono, seperti contoh-contoh berikut ini.

Contoh petium alterntif :

\section{Primair :}

a. Mengabulkan gugatan penggugat untuk seluruhnya.

b. Menyatakan sah perjanjian yang dibuat antara penggugat dengan tergugat.

c. Menyatakan tergugat telah ingkar janji (wanprestatie)

d. Menghukum tergugat untuk memenuhi isi perjanjian, dengan cara menyerahkan kepada Penggugat 1 (satu) ton beras dengan mutu kualitas super, merek rojo lele, dalam keadaan baik, selambat-lambatnya 7 (tujuh) hari terhitung sejak putusan ini diucapkan.

Dan seterusnya .......

\section{Subsidair :}

a. Mengabulkan gugatan penggugat untuk seluruhnya.

b. Menyatkan sah perjanjian yang dibuat antara penggugat dengan tergugat.

c. Menyatakan tergugat telah ingkar janji (wanprestatie).

d. Menyatakan perjanjian antara penggugat dengan tergugat bubar, terhitung sejak tanggal surat gugatan didaftarkan di pengadilan.

e. Menghukum tergugat untuk mengembalikan kepada penggugat, uang pembelian yang sudah diterima sejumlah sekian rupiah, selambatlambatnya 7 (tujuh) hari terhitung sejak putusan ini diucapkan.

f. Menghukum tergugat untuk membayar ganti rugi sejumlah sekian rupiah.

g. Dan seterusnya ....

Atau : Memberikan putusan yang seadil-adilnya / ex aequo et bono. (Achmad Fauzan 2007 : 67) 
12. Salam penutup

13. Nama terang Penggugat dan / atau kuasanya

14. Tanda tangan Penggugat dan / atau kusanya

Setelah surat gugatan selesai disusun atau dibuat, maka surat gugatan itu harus ditanda tangan Penggugat atau kuasa hukumnya apabila menguasakan, hal ini diatur dalam Pasal 118 ayat 1 HIR / RIB dalam hal Penggugat buta huruf, maka gugatan diajukan dengan lisan kepada Ketua Pengadilan kemudian ketua pengadilan mencatat gugatan itu atau menyuruh orang lain (pegawainya) untuk mencatat (Pasal $120 \mathrm{HIR/RIB}$ ) lalu dibubuhi cap jempol (cap ibu jari) Penggugat dan dilegalisasi oleh Ketua Pengadilan.

\section{KESIMPULAN}

Bahwa prinsipnya menyusun Surat Gugatan selain harus menguasai materi pokok permasalahan juga harus menguasai ketentuan hukum, lebih dari itu dibutuhkan pengetahuan yang luas untuk memenuhi prinsip jelas, lengkap dan sempurna, agar menghindari dari kelemahan yang dapat dieksepsi oleh pihak lawan, sehingga dapat menimbulkan kerugian biaya dan waktu bahkan menimbulkan kesan kurang profesional. 


\section{DAFTAR PUSTAKA}

Fauzan, Achmad, dan Suhertanto,. Teknik menyusun gugatan perdata di Pengadilan Negeri, Y. Rama Widya. Bandung, 2007.

Soeroso R., Praktik Hukum Acara Perdata, Tata Cara dan Proses Persidangan, Sinar Grafika, Jakarta, 2006.

Susilo, Budi, Prosedur Gugatan Cerai, Pustaka Yustisia, Yogyakarta, 2007. 